Revue belge de géographie

\title{
The urban geography of advanced producer service transaction links in Belgium
}

De stedelijke geografie van zakelijke transactielinks in België

\section{Heidi Hanssens and Ben Derudder}

\section{(2) OpenEdition}

\section{Journals}

\section{Electronic version}

URL: http://journals.openedition.org/belgeo/6345

DOI: $10.4000 /$ belgeo. 6345

ISSN: 2294-9135

\section{Publisher:}

National Committee of Geography of Belgium, Société Royale Belge de Géographie

\section{Printed version}

Date of publication: 30 June 2011

Number of pages: 17-28

ISSN: 1377-2368

\section{Electronic reference}

Heidi Hanssens and Ben Derudder, «The urban geography of advanced producer service transaction links in Belgium », Belgeo [Online], 1-2 | 2011, Online since 15 December 2012, connection on 02 May 2019. URL : http://journals.openedition.org/belgeo/6345 ; DOI : 10.4000/belgeo.6345

This text was automatically generated on 2 May 2019.

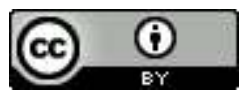

Belgeo est mis à disposition selon les termes de la licence Creative Commons Attribution 4.0 International. 


\section{The urban geography of advanced producer service transaction links in Belgium}

De stedelijke geografie van zakelijke transactielinks in België

Heidi Hanssens and Ben Derudder

\section{Introduction}

1 For many decades, Christaller's (1933) central place theory has perhaps been the single most important influence in conceptual and empirical research on the spatiality of urban systems. Although there seems to be a widespread consensus that the relevance of this theory for understanding contemporary city systems is disappearing, it can be noted that its implicit line of thinking still pervades the urban geography literature. One obvious example is the research on the rise of so-called "world cities", which inter alia serve as key territorial platforms in the (re)production of the global economy. According to Saey et al. (2005), a Christallerean approach is still observable in this research domain in that world cities are often deemed to be the (logical) outcome of a new scale of economic integration (in turn enabled by technological advances), resulting in a set of central places with a geographical range larger than initially envisioned by Christaller. Hall (2002), for instance, describes world city-formation as a simple addition of two scales atop Christaller's initial central place model (i.e. "world cities" such as London and Paris, and "sub-world cities" such as Manchester and Lyon).

Saey et al. (2005), however, refute Hall-like (2002) theorizations, and suggest that Taylor's (2004) research on the "world city network" (WCN) may provide the conceptual and empirical raw material to provide a better alternative in this context. Taylor's approach diverges from classical central place thinking on two crucial accounts. First, the primary focus is no longer on the urban centrality of service provision to households, but rather on the urban centrality of service provision with the explicit purpose of ensuring 
speeding-up capital circulation and accumulation (i.e. advanced producer services (APS) offered to firms). This is relevant as it brings the analysis of city-systems closer to a (more appropriate) conceptualization of cities as critical nodes in a globalizing capitalist economy rather than a market economy. Second, the dominant geographical principle of the overall system is no longer sought in a nested hierarchy of cities with nonoverlapping hinterlands, but rather in the overall degree of connectivity in inter-urban flows. In Taylor's specification of the WCN, cities are inter-linked through the multi-office location strategies of globalized APS firms, which reflects their aspiration to offer a seamless global service to their clients. To describe the geographical outline of the WCN, Taylor thus introduces the concept of overlapping "hinterworlds", defined as cities' capacity and distribution of service connections.

In the spirit of Saey et al.'s (2005) appreciation of Taylor's (2004) work, in this paper we examine how the geographies of APS provision can inform our understanding of the transformation of city-systems. However, our approach is somewhat different from that of Taylor (2004) in that (i) we will concentrate on the implications for urban systems at different scales rather than making a straightforward scalar jump to "world cities" (which arguably avoids some of the reification involved in the pre-factum identification of "world cities") ; (ii) our approach makes use of data on inter-firm rather than intrafirm links to measure inter-city relations ; and (iii) rather than assuming that cities are connected based on the mere co-presence of APS firms, we focus on the actual transaction links between APS firms and their clients (which arguably implies a more concrete measure of inter-city networking).

Our argument will be based on two juxtaposed sets of empirical analyses. First, we describe the urban geography of APS transaction links generated by the largest companies located in Belgium. Second, we present an explanatory analysis of this urban geography, whereby we mainly explore where in the corporate hierarchy decisions on outsourcing are being made. Based on our results, the paper is concluded with an overview of some of the implications for the study of urban systems in the context of economic globalization. Before turning to the discussion of our results, however, we first present a brief outline of our data collection.

\section{Data collection}

Between 7 June and 22 November 2009, we sent out a questionnaire to the top-300 companies in Belgium ${ }^{1}$, asking them to identify and locate their main business partner for those APS that were outsourced during the last year of operation. The list of APS included (i) accountancy-audit; (ii) financial services-creditor bank; (iii) insurance; (iv) legal services; (v) management consultancy; (vi) advertising; and (vii) information and communication technologies (ICT). Of the 300 companies, we received 118 responses. Of these 118 responses, 97 included a completed questionnaire ; the remaining 21 companies indicated that they would not participate as the required information was considered too confidential.

6 Table 1 lists the distribution of the population (300 companies) and the sample (97 companies) by administrative region and economic sector ${ }^{2}$.It shows how half of Belgium's top-300 companies are located in the Brussels Capital Region (BCR). The large majority of the remaining companies are located in the Flemish Region, while the Walloon Region only accommodates 28 companies. The last column compares the relative 
distribution of the sample with the relative distribution of the population. It shows that Walloon companies are quite underrepresented in the sample, whereas companies in the $B C R$ are somewhat overrepresented. Obviously, this will have consequences for the geography of APS procurement in general, and for the occurrence of Walloon service cities in our dataset in particular. The relative distribution of Flemish companies on the other hand is more or less the same.

Table 1. Distribution of firm population (300 companies) and sample ( 97 companies) by location and economic sector.

\begin{tabular}{|c|c|c|c|c|c|}
\hline & Population & $\begin{array}{l}\% \\
\text { Pop }\end{array}$ & Sample & $\begin{array}{l}\% \\
\text { Sample }\end{array}$ & RATIO \\
\hline Flanders & 122 & 40,67 & 39 & 40,21 & 0,99 \\
\hline Brussels Capital Region & 150 & 50,00 & 54 & 55,67 & 1,11 \\
\hline Wallonia & 28 & 9,33 & 4 & 4,12 & 0,44 \\
\hline C : Manufacturing & 108 & 36,00 & 39 & 40,21 & 1,12 \\
\hline $\begin{array}{l}\text { D : Electricity, gas, steam and air conditioning } \\
\text { supply }\end{array}$ & 15 & 5,00 & 3 & 3,09 & 0,62 \\
\hline $\begin{array}{l}\mathrm{E}: \text { Water supply, sewerage, waste } \\
\text { management... }\end{array}$ & 4 & 1,33 & 1 & 1,03 & 0,77 \\
\hline $\mathrm{F}$ : Construction & 5 & 1,67 & 2 & 2,06 & 1,24 \\
\hline G: Wholesale and retail trade... & 109 & 36,33 & 33 & 34,02 & 0,94 \\
\hline $\mathrm{H}$ : Transporting and storage & 16 & 5,33 & 5 & 5,15 & 0,97 \\
\hline $\mathrm{J}:$ Information and communication & 12 & 4,00 & 5 & 5,15 & 1,29 \\
\hline $\mathrm{K}$ : Financial and Insurance activities & 12 & 4,00 & 4 & 4,12 & 1,03 \\
\hline L Real estate activities & 1 & 0,33 & 0 & 0,00 & 0,00 \\
\hline $\begin{array}{l}\text { M : Professional, scientific and technical } \\
\text { activities }\end{array}$ & 4 & 1,33 & 0 & 0,00 & 0,00 \\
\hline $\begin{array}{l}\mathrm{N} \text { : Administrative and support service } \\
\text { activities }\end{array}$ & 11 & 3,67 & 4 & 4,12 & 1,12 \\
\hline $\mathrm{P}$ : Education & 1 & 0,33 & 1 & 1,03 & 3,09 \\
\hline Q: Human health and social work activities & 1 & 0,33 & 0 & 0,00 & 0,00 \\
\hline $\mathrm{R}$ : Arts, entertainment and recreation & 1 & 0,33 & 0 & 0,00 & 0,00 \\
\hline
\end{tabular}


7 Similar observations can be made for the sectoral distribution of the companies. As Table 1 shows, over two thirds of Belgium's largest firms are active in manufacturing (NACE section C) and wholesale \& retail trade (NACE section G). The sample displays a comparable sectoral distribution. Only NACE sections D and E are slightly underrepresented, while information \& communication firms (NACE section J) are somewhat overrepresented.

The result of our survey was a list of 358 transaction links, indicating for each link (i) the location of the "user firm" (we term this the "user" city, as this is where the service is "consumed") ; (ii) the location of the "service firm" (i.e. the "service" city, as this is where the service is "produced"); and (iii) the APS sector of the service firm. Municipalities' postal codes were collected as the initial data to locate both user and service firms. However, to avoid an impractical high degree of geographical detail, we aggregated the individual municipalities to the level of their urban fields ${ }^{3}$ and used these urban fields to identify the respective user and service cities. Municipalities that do not belong to an urban field were listed individually.

9 In addition to this survey, we also scanned the user firms' websites to collect additional corporate information on (i) their ownership structure (distinguishing between Belgian private ownership, foreign private ownership, mixed Belgian/foreign ownership, and autonomous government companies) ; and (ii) their position in the corporate hierarchy (distinguishing between global headquarters, regional/divisional headquarters, and subsidiaries).

\section{Results}

\section{The geography of APS procurement by large companies in Belgium}

10 To explore the spatiality of APS procurement by large companies in Belgium, we computed a matrix that lists the number of transaction links between each of the 21 user cities and each of the 32 service cities in our sample (Table 2). The table provides information on the size and direction of the individual city-to-city relations. It shows, for instance, how all but 3 of the 21 user cities share at least one link with Brussels and how 14 of them (Brussels included) even rely on this city for a majority of their transaction links. Geel, where the European division of Hyundai Heavy Industries is located, is the only city that procures a majority of its links in Antwerp. 
Table 2. Service city to user city transaction link matrix.

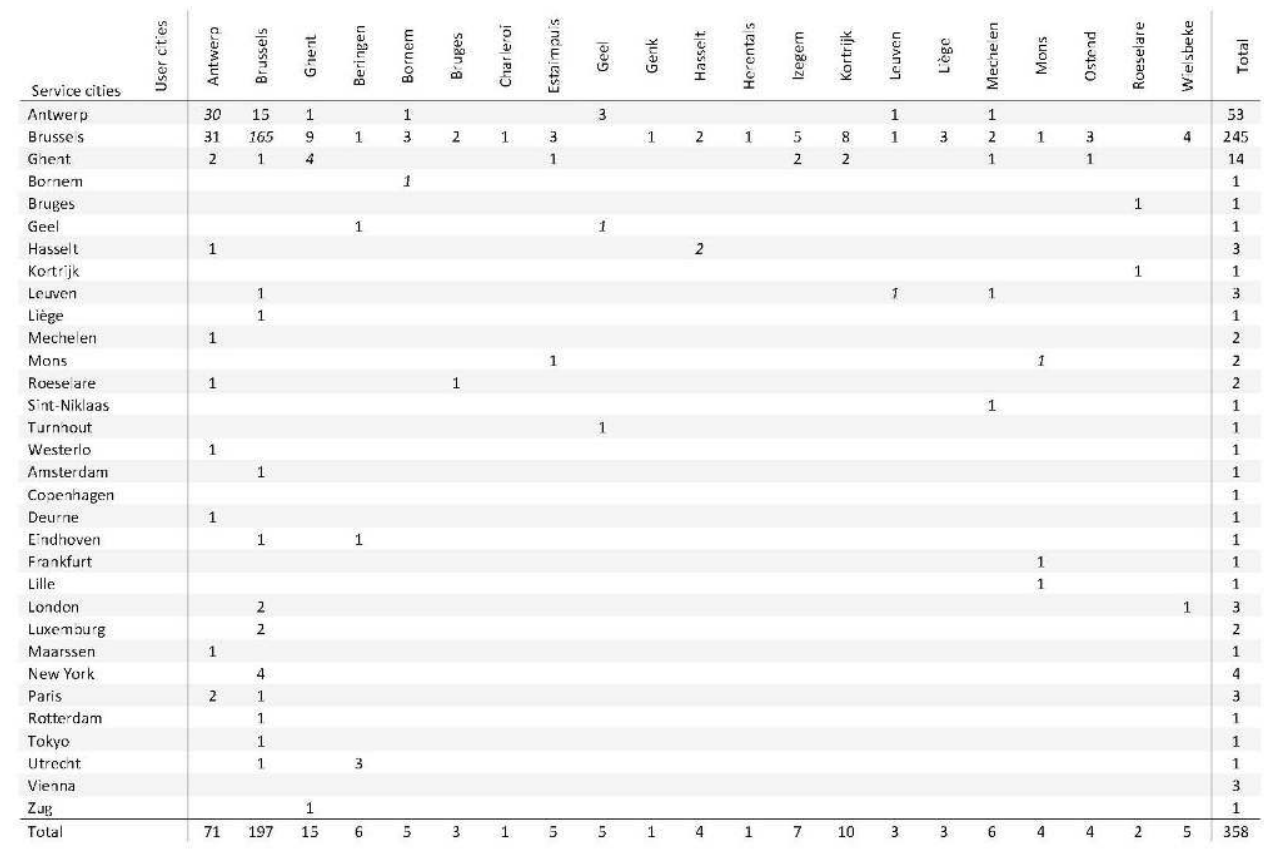

11 The scores in the last column represent the total APS supply for each service city. Once again, Brussels stands out: out of 358 transaction links, 245 (64\%) are purchased from APS firms located in the capital, while Antwerp merely accommodates 53 (14\%) service provisions and Ghent only $14(4 \%)$. The few remaining transaction links are procured from a limited number of urban fields and individual - both Belgian and foreign municipalities. Most of the foreign service cities are located in the neighbouring countries, i.e. the Netherlands, the UK, France, and Germany. The only two service cities located outside Europe are Tokyo and New York.

Because Brussels, Antwerp and Ghent are the only user and service cities with a more or less significant economic role (i.e. the starting point or destination of more than 10 transaction links), the relative share of the remaining cities in either service demand or service supply is very small. This implies that it becomes difficult to formulate meaningful statements about the geography of the remaining transaction links, and we therefore aggregated our data in two steps.

In a first step, we grouped all Belgian cities with 10 or less links in a single "residual" category (e.g. Bruges, Liège, Ostend...) and all foreign cities in a single "international" category (e.g. Amsterdam, Copenhagen, Deurne (North Brabant)...). Table 3 represents the aggregated version of the basic matrix shown in Table 2. The table shows, for instance, that cities of the residual category procure 14 APS in other cities of the residual category, of which 6 APS are procured from within the same city.

Table 3. Aggregated service city to user city transaction link matrix.

\begin{tabular}{|l|l|l|l|l|l|l|}
\hline Service cities & User cities & Antwerp & Brussels & Ghent & Residual & Total \\
\hline Antwerp & & 30 & 15 & 1 & 7 & 53 \\
\hline
\end{tabular}




\begin{tabular}{|l|l|l|l|l|l|l|}
\hline Brussels & & 31 & 165 & 9 & 40 & 245 \\
\hline Ghent & & 2 & 1 & 4 & 7 & 14 \\
\hline Residual & & 4 & 2 & 0 & $14(6)$ & 20 \\
\hline International & & 4 & 14 & 1 & 7 & 26 \\
\hline Total & & 71 & 197 & 15 & 75 & 358 \\
\hline
\end{tabular}

In a second step, we aggregated the transaction links into three new location categories, being intra-city, national inter-city and international inter-city transaction links. The pie chart in Figure 1 visualizes the result of these aggregations. The chart is divided by means of a dual classification. The first level classifies all transaction links in terms of intra-city, national inter-city and international inter-city links. The second level subdivides each of these three categories individually in terms of the share of each service city. Only the international inter-city category is subdivided in terms of user cities rather than service cities. In this way, Figure 1 specifies for instance how many of the intra-city links are procured in Antwerp (i.e. 30); how many of the national inter-city transaction links are supplied by APS firms located in Antwerp to user firms located elsewhere in the country ( i.e. 23) ; and how many of the international inter-city links are procured by user firms located in Antwerp (i.e. 3).

Figure 1. Classification of transaction links by location category.

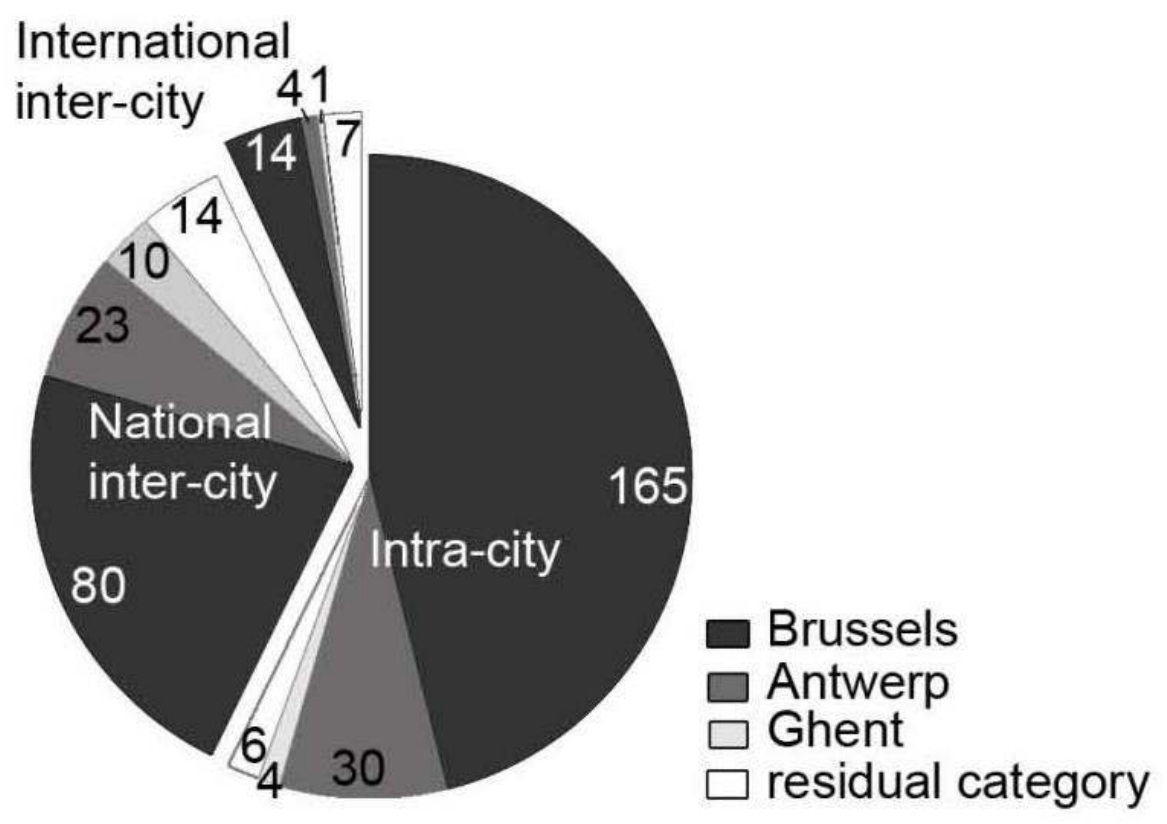

15 When combining Figure 1 and Table 3, we can derive three main features of the geography of APS procurement by large companies in Belgium. First, the pie chart shows how the majority of transaction links are procured within the own city. The dominance of intra-city links in our dataset is however mainly due to the large share of intra-city links 
in Brussels, which is in turn partly explained by the fact that 54 of the 97 user firms in our sample are located in the capital city. However, the distribution of transaction links for the national inter-city category shows that Brussels is not only acting as a service city for user firms located in the city itself, but also for user firms located elsewhere in the country. The overall dominance of Brussels as a service city is thus a first feature of the geography of APS procurement by Belgium's largest companies.

A second feature is that, when looking beyond links with Brussels, the remaining national transaction links display a criss-cross pattern of (i) services procured by user firms located in the smaller cities of the residual category from APS firms located in the larger cities Antwerp and Ghent ; (ii) transaction links going in the opposite direction, namely procured by user firms in Antwerp or Ghent from APS firms in the cities of the residual category; and (iii) transaction links between the cities of the residual category themselves. In other words, when it comes to APS provision to large companies, the urban spheres of influence of both large and smaller service cities in Belgium clearly overlap.

Finally, a third feature of the urban geography of service procurement in Belgium is the occurrence of 26 transaction links with service cities abroad. This demonstrates how the urban spheres of influence of service cities are not restricted by national borders.

\section{Exploring some driving forces behind the observed geography}

Now that we have described the geography of APS procurement by Belgium's largest companies, a second step is to explore some of the driving forces behind the observed geography. In general, most of the intra-city and national inter-city transaction links in our dataset can be explained as being the result of (a combination of) space-related and/ or quality-related decision factors. The dominance of Brussels as service city for instance can be mainly ascribed to (i) its overall relative proximity as the city is centrally located in a small country with a well-established infrastructure; (ii) its function as both state capital and capital of the European Union; and - closely related to this - (iii) its world city status in the sense that globalizing APS firms have set up shop in Brussels in the context of their globalized office networks (Taylor, 2004 ; Aujean et al., 2007 ; Derudder $e t$ al., 2010). Moreover, as Vandermotten et al. (2006, p. 148) argue: "Many MNCs setting up in Belgium opt for a location in Brussels or its periphery, without trying to establish subsidiaries in other Belgian cities. [...] Due to the small size of the country, these firms have no difficulty in servicing the whole of the national market from their Brussels base."

It is however less obvious whether the transaction link between, say, Brussels and Vienna was primarily based on (i) the choice of the APS firm's location in Vienna (which is rather unlikely as Vienna is neither ranked prominently in APS-based world city rankings nor a prime service centre for a particular APS sector); (ii) the characteristics of that firm regardless of it being located in Vienna ; or (iii) even no "choice" at all in the sense that the APS firm could have been imposed on the Belgian firm by its (presumably Austrian) parent company. As we have shown in an earlier paper on this topic (Hanssens et al., 2010), the geography of transaction links entails more than spatiality s.s. : it also refers to where in the overarching MNC structure the decision(s) regarding these transaction links are made. In our survey, we implicitly assumed a heterarchical form of organization in which the choice for a particular APS is left at the discretion of the local management. However, although research on such heterarchical forms of organization in MNCs does 
indeed emphasize that corporate power is far more decentralized and diffuse than often presumed (Dicken and Malmberg, 2001; Jones, 2002), it can be argued that a strict heterarchical organization represents just one end of a continuous spectrum of organizational structures. The other end is represented by more hierarchical forms of corporate organization where the choice for a particular APS is imposed by a corporate hierarchy. For firms whose organizational structure displays a tendency towards the latter, decisions on outsourcing are made elsewhere, which has of course important implications for the geography of transaction links.

As our questionnaire did not inquire on the process behind APS outsourcing, we cannot directly identify those cases. There is, however, an indirect way to address this question. As already mentioned in the overview of our data collection exercise, our dataset also contains information on the ownership structure of the user firms (distinguishing between Belgian private ownership, foreign private ownership, mixed Belgian/foreign ownership, and autonomous government companies) and their position in the corporate hierarchy (distinguishing between global headquarters, regional/divisional headquarters, and subsidiaries). By means of a Pearson Chi-square test of independence, we assessed the statistical significance of the relationship between both these variables and the location decision for transaction links in terms of intra-city, national inter-city and international inter-city relations. The results of these measurements are listed in Table 4. The table shows that, because for each pair of variables the calculated Chi-square statistic (column 2) is larger than the critical measure (column 4 ) at the $0.1 \%$ significance level, there is indeed a statistically significant relationship between both sets of variables. However, as Pearson Chi-square provides no information on the strength of this relationship, we also computed the Cramer's V for each pair of variables. Cramer's V is a measure of association based on Chi-square and ranges between 0 and 1, with 0 indicating no association between both variables, and values close to 1 indicating a high degree of association. The results are listed in the last column of Table 4 . They display relatively low scores. Taken together, we can thus conclude that there is a weak but statistically significant relationship between ownership structure and location choice on the one hand, and position in the corporate hierarchy and location choice on the other hand.

Table 4. Results of Pearson Chi-square test of independence and Cramer's V.

\begin{tabular}{|l|l|l|l|l|}
\hline & $\begin{array}{l}\text { Pearson Chi- } \\
\text { square }\end{array}$ & $\mathrm{df}$ & $\begin{array}{l}\text { Threshold of probability } \\
(0.001)\end{array}$ & $\begin{array}{l}\text { Cramer's } \\
\mathrm{V}\end{array}$ \\
\hline $\begin{array}{l}\text { Ownership - location } \\
\text { choice }\end{array}$ & 37.015 & 6 & 22.46 & 0.227 \\
\hline Position - location choice & 30.109 & 4 & 18.47 & 0.205 \\
\hline Ownership - position & 209.380 & 6 & 22.46 & 0.541 \\
\hline
\end{tabular}

21 Figures 2 and 3 explore this relationship in greater detail. The pie charts in Figure 2 visualize the distribution of transaction links for each ownership category individually. Especially the distribution of the foreign transaction links is of particular interest here. The pie charts show that - except for one foreign transaction link by a Belgian company only user firms with a (partial) foreign ownership buy APS abroad. 
Figure 2a-d. Disaggregation of transaction links by firm ownership.

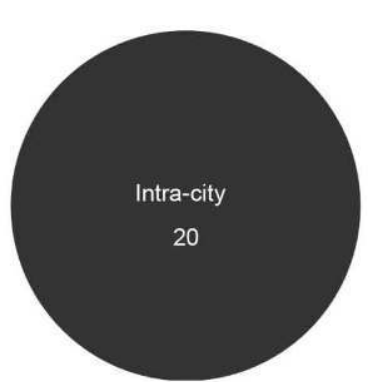

a. A.G.C.

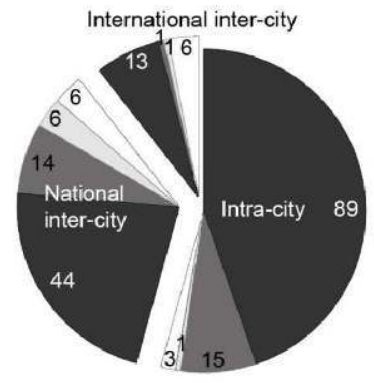

c. Foreign owned

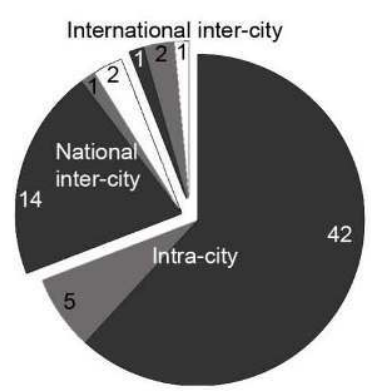

b. Belgian/foreign owned

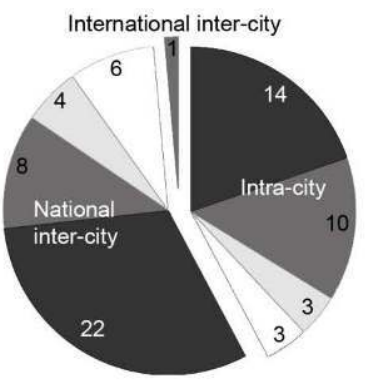

d. Belgian owned

Figure 3a-c. Disaggregation of transaction links by position in corporate hierarchy.

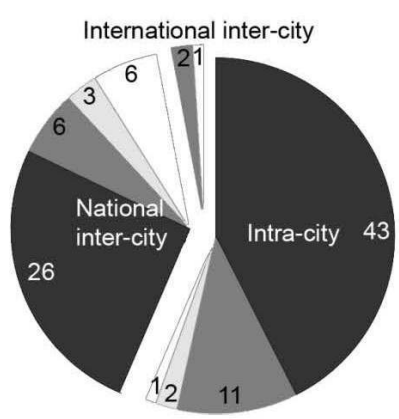

a. Global headquarters

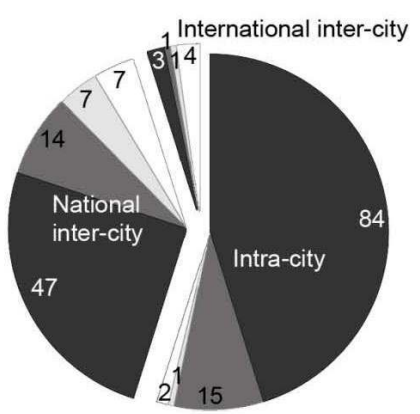

c. Subsidiary

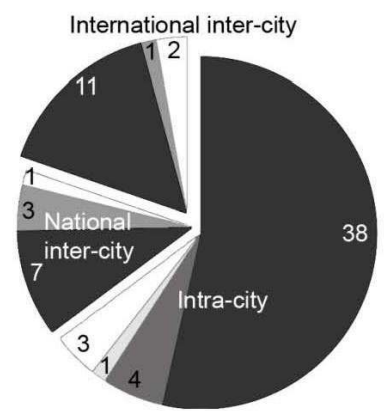

b. Regional/divisional headquarters

22 Pie charts a-c in Figure 3 disaggregate the distribution of transaction links in terms of a user firm's position in the corporate hierarchy. The most remarkable feature here is the 
large number of international inter-city links for regional/divisional headquarters. The majority of these links originates in Brussels. Subsidiaries also procure APS abroad, albeit to a much lesser degree. Global headquarters located in Belgium only display three international inter-city links.

The last row in Table 4 provides a partial explanation for these observations. The figures show a relatively strong relationship between the ownership structure of the user firms and their position in the corporate hierarchy. In specific terms this means that - to a certain extent - global headquarters display relatively few foreign transaction links because the majority of these companies are Belgian owned (51.5\%) or autonomous government companies (10.9\%), whereas regional/divisional headquarters, which generate the majority of foreign transaction links, are generally foreign owned (56.3\%) or mixed Belgian/foreign owned ( $28.2 \%)$ companies. For subsidiaries this relationship is less straightforward. Although more than $90 \%$ of all subsidiaries are foreign owned (85.5\%) or mixed Belgian/foreign owned (5.4\%), they only represent 6 international APS links.

The fact that on the one hand only companies with a (partial) foreign ownership, and on the other hand mainly regional/divisional headquarters and subsidiaries display international inter-city links can be considered as a first indication of the involvement of the parent company in outsourcing decisions. To further explore this assumption, we compared the location of the user firm's parent company or holding to the location of the foreign transaction choices. In 12 of the 26 links, we found a match. For instance, a manufacturing company located in Brussels with headquarters in New York indicated that it receives several of its services (i.e. accountancy/audit, financial services, insurance, and management consultancy) from APS firms located in New York. Although this is of course an indirect approach, it is a strong indication that for these transaction links, the actual decision making on outsourcing does not happen in Belgium.

\section{Discussion and conclusions}

It can be said that the results of the different empirical analyses contain few surprises : the observations that (i) Brussels is the major centre for APS procurement of major companies located in Belgium and that (ii) the mounting importance of MNCs goes hand in hand with the internationalization of service procurement may not come as a surprise. However, the key point here is that these observations - more so than Taylor's (2004) analysis of WCNs - clearly show that a Christallerean approach to urban centrality is not well-suited to understand the urban geography of service provision to firms in the context of economic globalization. As a consequence, Hall's (2002) formulation of a revamped city-system by simply including new layers of service provision to Christaller's initial scheme fails to recognize the nature and geography of service provision under conditions of contemporary economic globalization.

In this paper, we have tried to tease out some of the basic principles of alternative theorizations of the spatiality of central place systems. In our reading, the empirical description of centrality in APS provision to large companies in Belgium leads to three general principles that need to be taken into account in these theorizations: (i) world city-formation as described by Sassen (2001) does seem to have an impact in that the presence of sizable APS clusters in a limited number of urban centres reproduces a spatial focus on a single central city; (ii) however, the pattern is far more complex in that, contrary to Christaller's notion of discrete hinterlands, over and beyond this focus on a 
single dominant node there are also criss-cross patterns of transaction links between larger and smaller cities in both directions as well as between smaller cities ${ }^{4}$; furthermore (iii) this complex overlap of urban spheres of influence supersedes national borders in general and Euclidean space particularly, i.e. the indication that the geography of APS procurement depends on the insertion of firms in MNC hierarchies. Regarding the latter, more in-depth qualitative research is definitely needed to tease out the impact of the intra-firm distribution of decision-making power - be it in terms of hierarchical relations or functional relations - on the geography of APS procurement.

The results of our case study - and the dominance of Brussels in particular - should however also be partly nuanced in this context. The design of our case-study entails three potential biases favouring Brussels as a service city. First, we only focused on a restricted number of APS. Logistics or transportation, for instance, which are typical APS for port cities such as Antwerp or Ghent, were left out. Second, our questionnaire only inquired about the main business partner, and did therefore not distinguish between domestic and foreign business of the user firms. And finally, the case study explored the geography of transaction links by Belgium's top-300 companies. Apart from the fact that these large companies may use other decision criteria for selecting APS firms than small- and medium-sized enterprises (SMEs), they also appeared to be predominantly located in Brussels, which might partly explain the disproportionate share of intra-city links in the capital city. One future avenue for further research will therefore inter alia focus on some of these issues.

\section{BIBLIOGRAPHY}

AUJEAN L., CASTIAU E., ROELANDTS M., VANDERMOTTEN C. (2007), "Le positionnement des villes belges dans le réseau global des services avancés”, Belgeo, 8, 1, pp. 15-29.

CHRISTALLER W. (1933), Die zentralen Orte in Süddeutschland, Jena, Gustav Fischer.

DERUDDER B., TAYLOR P. J., NI P., DE VOS A., HOYLER M., HANSSENS H., BASSENS D., HUANG J., WITLOX F. \& YANG X. (2010), "Pathways of growth and decline : connectivity changes in the world city network, 2000-2008”, Urban Studies, 47, pp. 1835-1841.

DICKEN P. \& MALMBERG A. (2001), "Firms in territories : a relational perspective”, Economic Geography, 77, pp. 345-363.

HALL P. (2002), "Christaller for the global age : redrawing the urban hierarchy", in MAYR A., MEURER M. \& VOGT J. (eds.) Stadt und Region : Dynamik von Lebenswelten, Leipzig, Deutsche Gesellschaft für Geographie, pp. 110-128.

HALL P. \& PAIN K. (eds.) (2006), The Polycentric Metropolis : Learning from Mega-City Regions in Europe , London, Earthscan.

HALLEUX J.M. (2002), “Commented bibliography on Belgium”, in COST ACTION C10, Outskirts of European Cities. State of the Art Report, Brussels, European Commission, pp. 26-44. 
HANSSENS H., DERUDDER B. \& WITLOX F. (2010), Managing organizational and geographical complexity: on the "positionality" of advanced producer services in global production networks, under review.

JONES A. (2002), “The 'global city' misconceived : the myth of 'global management"' in transnational service firms”, Geoforum, 33, pp. 335-350.

LUYTEN S. \& VAN HECKE E. (2007), De Belgische Stadsgewesten 2001, Brussel, Algemene Directie Statistiek en Economische Informatie.

PAIN K. (2008a), "Examining core-periphery relationships in a global mega-city region - the case of London and South East England", Regional Studies, 42, pp. 1161-1172.

PAIN K. (2008b), "Looking for the 'core' in knowledge globalization : the need for a new research agenda", GaWC Research Bulletin 286, http ://www.lboro.ac.uk/ gawc/rb/rb286.html.

ROSSI E. C., BEAVERSTOCK J. V. \& TAYLOR P. J. (2007), “Transaction links through cities : 'decision cities' and 'service cities' in outsourcing by leading Brazilian firms", Geoforum, 38, pp. 628-642.

SAEY P., VAN NUFFEL N. \& DERUDDER B. (2005), "Verkeer en de teloorgang van het ommeland", De Belgische Geografendagen, Deel II. Mobiliteit, maatschappij en milieu in kaart gebracht, pp. 221-226.

SASSEN S. (2001), The Global City. New York, London, Tokyo, Princeton, Princeton University Press.

TAYLOR P. J. (2004), World City Network : a Global Urban Analysis, London, Routledge.

VAN OORT F., VAN BRUSSEL J., RASPE O., BURGER M., VAN DINTEREN J. \& VAN DER KNAAP B. (2006), Economische netwerken in de regio, Rotterdam, NAi Uitgevers.

VANDERMOTTEN C., ROELANDTS M., AUJEAN L. \& CASTIAU E. (2006), “Central Belgium : polycentrism in a federal context”, in HALL P. \& PAIN K. (eds.) The Polycentric Metropolis : Learning from Mega-City Regions in Europe, London, Earthscan, pp. 146-153.

\section{NOTES}

1. Belgium's top 300 firms as listed on the website of Trends Top (http ://trendstop.rnews.be, Accessed : 11 May 2009). This ranking is based on corporate turnover figures for the fiscal year 2007.

2. Information on the location (address) and economic sector (NACE-code) of the user firm was also obtained from the website of Trends Top (http ://trendstop.rnews.be, Accessed: 11 May 2009).

3. In Belgium, an urban field (stedelijk leefcomplex, also called Metropolitan Region ; Halleux, 2002) consists of an urban region and its commuter area. The former is a combination of a city's operational agglomeration and the urban fringe. The latter includes those municipalities in which at least fifteen percent of the active population commutes to the respective agglomeration. Belgium has eighteen urban regions (and hence also eighteen urban fields). All urban fields together represent $51 \%$ of the Belgian territory and $75 \%$ of its total population (Luyten and Van Hecke, 2007).

4. These results are largely in line with similar research on the external relations of cities based on corporate relations in other urban systems (see, amongst others, van Oort et al., 2006 ; Rossi et al., 2007 ; Hall \& Pain, 2006 ; Pain, 2008a, 2008b). 


\section{ABSTRACTS}

This paper aims to contribute to the literature on the geography of external relations of cities. Our overall purpose thereby is to tease out some of the basic principles of alternative approaches to the study of the spatiality of urban systems in the context of economic globalization. To this end, we present an empirical analysis of the urban geography of producer service procurement by 118 of the 300 largest companies in Belgium. The main features of this urban geography of service procurement include (i) the dominance of Brussels as a service city ; (ii) the existence of overlapping urban spheres of influence; and (iii) the presence of transaction links with foreign cities. The results of our analysis also suggest that, in addition to space- and quality-related decision factors, the intra-firm distribution of decision-making power in multinational firms equally influences the spatiality of transaction links. The relevance of these results is discussed in the context of theorizations of urban systems.

Dit artikel levert een bijdrage tot de literatuur die de geografie van externe stedelijke relaties bestudeert. Onze overkoepelende doelstelling is om enkele van de basisprincipes bloot te leggen van alternatieve benaderingen in de studie van de geografie van stedelijke systemen in de context van economische mondialisering. De empirische analyse die de basis vormt voor deze studie, bestudeert de stedelijke geografie van transactielinks tussen 118 van de de 300 grootste bedrijven in België en hun voornaamste zakenpartners voor een aantal "productieve diensten". De belangrijkste kenmerken van deze stedelijke geografie van transactielinks zijn (i) de dominantie van Brussel als dienstenstad; (ii) de aanwezigheid van overlappende stedelijke invloedssferen; en (iii) de aanwezigheid van transactielinks met steden in het buitenland. De resultaten van onze analyse geven ook aan dat - naast ruimte- en kwaliteitsgerelateerde beslissingsfactoren - de verdeling van beslissingsbevoegdheden binnen multinationale firma's eveneens een invloed heeft op de geografie van deze transactielinks. De relevantie van deze resultaten wordt besproken in de context van theorievorming rond stedelijke systemen.

\section{INDEX}

Keywords: urban systems, transaction links, producer services, Belgium, economic globalization motsclesnl stedelijke systemen, transactielinks, productieve diensten, België, economische mondialisering

\section{AUTHORS}

\section{HEIDI HANSSENS}

Ghent University, Department of Geography, heidi.hanssens@gmail.com

\section{BEN DERUDDER}

Ghent University, Department of Geography, Ben.Derudder@ugent.be 